\title{
Tomasz Galkowski
}

University of Cardinal Stefan Wyszyński, Warsaw, Poland

(D) https://orcid.org/0000-0001-9166-9516

\section{Participation in the "Synodal Way": A Few Comments in the Light of Karol Wojtyła's Theory of Participation}

\begin{abstract}
Announcing in the German Church the so called synodal way provoked discussions concerning the participation and joint responsibility of all the faithful in the implementation of the Church mission, especially with regard to exercising power and making binding decisions. The aim of the presented reflections (comments) is to look at the discussion in the light of the theory of participation, analysed by Karol Wojtyła in his work The Acting Person. The co-existence of the community of action and the personal value of the act and experiencing as one's own jointly made decisions may set the direction for new paradigms of exploring sensus fidei.
\end{abstract}

Keywords: synodal way, participation, Karol Wojtyła, theory of participation

Addressing the issue of participation and responsibility, especially with regard to exercising power has been provoked by current discussions concerning the so called synodal way in the Church, which is a supernatural community as the sign and instrument of salvation. Therefore, it is the community in which and through which the vocation to life of the saved ones is realized, as "it pleased God to call men to share His life, not just singly, apart from any mutual bond, but rather to mold them into a people in which His sons, once scattered abroad might be gathered together."1

${ }^{1}$ Vatican Council II, Decree on the Mission Activity of the Church Ad gentes divinitus (7.12.1965), n. 2 
Such a community is for the baptized persons the environment which allows them to follow their vocation. The presence in the community is not passive. At the same time, the community becomes an obligation for the believer, since its development and growth result from Christ's order to pass on the gift of community which was first experienced by a person. The believer in the Church is endowed with the community and undertakes joint actions for its sake and for himself. The decision of faith is made at the level of an individual person ("myself") and remains a personal act, but has its source in the faith of the united "ourselves."

A personal act of faith has a community nature and expresses itself and is present at many levels of the Church community life. Building up a community and concern about its development is also expressed in decisions taken for its benefit. In this context, we can observe the appearance of voices demanding participation in decision-making concerning the community, including sovereign decisions.

It seems that Wojtyła's philosophical deliberations do not refer to the situation of the Church and the issue of participation from the perspective of current attempts to understand the issue of synodality. This aspect should be considered at the level of theological reflections. However, in the theory of participation presented in the work Osoba $i c z y n,{ }^{2}$ Wojtyła emhasizes "the aspect of a dynamic correlation between an act and a person, which results from the fact that people perform acts jointly with other people." 3 No different are the acts of participation of all the faithful in modus vivendi et operandi of the Church community. ${ }^{4}$ The synodical dimension of the Church both reflects and shapes the participation and responsibility of all the faithful building this Church.

In Wojtyła's reflections one can also find a methodical hint leading to conclusions in the context of theological deliberations. It is the distinction that the concept of participation is granted in the colloquial and philosophical meaning. Following this direction, one should refer to the concept of participation which has a long and rich history - in the language of both philosophy and theology. ${ }^{5}$ Pursuing this thought, it can be added that the idea of participation might turn out to be acceptable also in the system of canon law only with great difficulty and mental effort. The condition of making this effort gives the concept of participation a meaning characteristic for the Church community, noting at the

${ }^{2}$ The book by Karol Wojtyła was published in English under the title The Acting Person. I am using the text: Persona e atto. Testo polacco a fronte (Santarcangelo di Romagna: Rusconi Libri, 1999).

3 Wojtyła, Persona e atto, 614.

${ }^{4}$ International Theological Commision, Synodality in the Life and Mission of the Church (2.03.2018), n. 6, accessed May 15, 2020, http://www.vatican.va/roman_curia/congregations/ cfaith/cti_documents/rc_cti_20180302_sinodalita_en.html.

5 Wojtyła, Persona e atto, 630. 
starting point that its structural foundations result from Christ's will. Thus, this notion will considerably differ from the one granted by the theory and dogma of law.

The theory of participation discussed by Wojtyła is also far from contemporary problems concerning the contextual understanding of the issue of participation. ${ }^{6}$ It results from the fact that today's ways of understanding this idea restrict it to the category at the core of which is the distinction between the state and society, which in turn results in two different concepts: a citizen and a human person. ${ }^{7}$

The concept of a citizen is alien to the language of religion and the reality of Church different from the state. Closer to the language of religion and canon science is the definition of a person who in the Church is the baptized person. A man becomes a person in the Church thanks to receiving holy baptism (can. 96). However, this definition of a person has a technical connotation which is used to describe the position of the baptized person in the Church with his rights and responsibilities and not to express fully who he is. It is another reason why deliberations concerning the participation of the person in undertaking actions together with other people might not be fully adequate to the theory of the person analyzed by Wojtyła. A starting point for theological and canonistic reflections is the baptized person living and acting together with other people in the community of the Church.

The concept of participation indicates close connections between people and their joint actions through which and thanks to which the person is able to recognize his or her transcendence. Nevertheless, the same concepts not always turn out to be adequate to express the content they refer to. ${ }^{8}$ Similar wording, as pointed out by comparative linguistics, also has to take into consideration the position of words which they occupy in the structure of languages. Material similarity or vocabulary correlations co-exist with different, structural position of words in the language structure. Showing the structural relation of the word with its position in the language contributes to adequate presentation of connections related to vocabulary. Similarity of words does not equal similarity of meanings, even if the same words are used to express and name similar realities in different communities. The Church institutions, which might seem similar to secular ones, occupy a different structural position in the Church due to the fact that everything in the Church is subject to its redemptive mission. The language which describes it, although it uses similar vocabulary understandable

${ }^{6}$ Aristide Savignano, "Partecipazione," in Enciclopedia del diritto, vol. 32 (Milano: Giuffrè, 1982), 1-14.

${ }^{7}$ Libero Gerosa, Interpretacja prawa w Kościele. Zasady, wzorce, perspektywy (Kraków: WAM, 2003), 188.

8 Marian Żurowski, Współuczestnictwo kościelne. "Ius ad Communionem” (Kraków: WAM, 1979), 13. 
for the listeners, reflects the structural position of the described things and gains a new meaning. ${ }^{9}$

The above comments indicate that the concept of participation - as long as it is used with due care and refers to the structural position and place of the phenomena described by it-is not immediately doomed to failure and might find its place in the Church. However, the starting point cannot be a secular and political meaning of the concept which refers to the state organization. Participation in the Church is more and more widely discussed in the context of the so called synodal way, especially in terms of initiatives undertaken in the Church in Germany.

\section{Synodal Way of the Church in Germany}

In March 2019 German bishops with regard to the scandals of sexual abuse and loss of credibility announced the so-called synodal way, whose aim is internal purification leading to regaining the trust of the faithful. The process proposed by the bishops concerns a debate with participation of the faithful the subject of which is supposed to be the issue of broadly defined place of women in the Church, celibacy, changes in the Catholic sexual ethics as well as the issue of division of powers in the Church. ${ }^{10}$ The suggested topics were to become the subject of "binding synodal way," planned for the end of the year 2019, which the German bishops took together with the Central Committee of German Catholics (Zentralkomitee der deutschen Katholiken, ZdK). The current situation invokes, though not so clearly, the theses made by Karl Rahner who pointed out the need to establish a Germany-wide (or national) synod, consisting of bishops, presbyters and lay faithful. Such a synod would constitute the most important governing body in the national churches whose decisions would also have to be obeyed by the bishops. ${ }^{11}$

The statements of different German bishops regarding the character of decisions which will be made during this synodal way are not entirely explicit. Defining problems and raising questions is one thing and another thing is the

9 Joseph Ratzinger, "Demokratyzacja Kościoła," in Demokracja w Kościele. Możliwości i ograniczenia, ed. Joseph Ratzinger and Hans Maier (Kraków: Wydawnictwo Salwator, 2005), $21-22$.

${ }^{10}$ Krzysztof Tomasik, "Droga synodalna - tak, ale dokąd?” eKAI.pl, Magazyn internetowy Katolickiej Agencji Informacyjnej (September 16, 2019), accessed November 4, 2019, https://ekai.pl/droga-synodalna-tak-ale-dokad/.

${ }^{11}$ Ratzinger, "Demokratyzacja Kościoła," 35-36. 
binding character of the solutions and answers. From this perspective, the participation of the faithful in the matters of religion requires adequate answers but also the ones whose source is in one common faith of the Church. The faithful have the right to receive theological answers to the posed questions and recognized problems. The bishop of Münster Felix Genn expressed it by stating that "theological deepening of issues has not done harm to anybody so far, especially the Church." 12

The issue of greater meaning, which provoked a reaction of the Vatican and a letter of Pope Francis to the German bishops (29 June 2019), in which he expressed at first his appreciation of the German Catholics for their readiness to undertake reforms, regards the binding character of the synodal path. The Vatican criticized the bishops' stance, the fact that they want to decide about the issues which can be determined only on the forum of the universal Church. In addition, objection was raised against the equal right of bishops and secular people in voting. Cardinal Marc Ouellet, the Prefect of Congregation for Bishops, in the letter to the German bishops pointed out that decisions made in this way cannot have ecclesiological validity.$^{13}$ Archbishop Niokola Eterović, the Apostolic nuncio in Germany added his voice, reminding the bishops gathered at a meeting of the Episcopal Conference in Fulda (23-26 September 2019) about the words of the papal letter that the synod is not a parliament and the decisions of the bishops cannot have far-reaching consequences not only for the Church in Germany, and that issues connected with the heritage of faith cannot be the subject of negotiations of the particular Church. ${ }^{14}$ However, the tone of expression of the German bishops cannot be unambiguously interpreted as making the decisions taken by them together with the lay faithful absolutely binding. As a matter of fact, the bishop of Mainz Peter Kohlgraf defending the synodal way indicated the binding character of the discourse process, but added that it can be an impetus coming from the Church in Germany which should also be discussed at the level of the universal Church..$^{15}$ The chairman of the Central Committee of German Catholics Thomas Sternberg went even further and while calling for binding decisions he stated: "If the decisions shall concern the universal Church, we will bring them to Rome." 16 The statement of Sternberg, which can be interpreted in the light of concern about regaining the

12 eKAI.pl, "Niemieccy biskupi odrzucają stanowisko Watykanu ws. drogi synodalnej," eKAI.pl (September 24, 2019), accessed November 4, 2019,

https:/ekai.pl/niemieccy-biskupi-odrzucaja-stanowisko-watykanu-ws-drogi-synodalnej/.

13 Tomasik, "Droga synodalna - tak, ale dokąd?"

14 eKAI.pl (September 24, 2019), "Nuncjusz wzywa niemieckich biskupów do posłuszeństwa papieżowi," accessed November 4, 2019,

https:/ekai.pl/nuncjusz-wzywa-niemieckich-biskupow-do-posluszenstwa-papiezowi/.

${ }^{15}$ eKAI.pl, "Niemieccy biskupi odrzucają stanowisko Watykanu ws. drogi synodalnej."

${ }^{16}$ Ibid. 
trust lost by the Church, arouses some controversy but is also a challenge for the Magisterium of the Church. The controversy also relates to the possibility to make binding decisions in the particular Church with the participation of the lay faithful. A challenge for the Magisterium is presenting the character of power in the Church clearly by a comprehensible message which will unambiguously indicate the position of laymen in it so that it removes all the temptations to treat it as a form of escape from difficult and unclear issues. All the faithful have the right to receive a theological answer.

The objections to the planned activities involve fears that they can lead to breaking the unity with the universal Church, resulting in the creation of the national Church, which is what the archbishop of Cologne card. Rainer Maria Woelki warned against. ${ }^{17}$ The issue concerning making binding decisions on the synodal way is revived again and this is the reason for presenting them duly and constantly, but first of all making them present in all possible forms.

Another issue, apart from the form of exercising power and making binding decisions, which came to light in the situation of the Church in Germany concerns the power itself. The aforementioned bishop, Felix Genn, claimed in one of the interviews that the Church needs a new division of powers, especially a new relationship between the lay faithful and priests, chief and honorary ones, men and women. He added that he is willing to share his administrative authority so that the laymen could have their say.18 The reaction of the Vatican was strong. The objection concerned the equal rights of the bishops and laymen in voting.

The above two issues related to binding decisions made on the synodal way and the character of the ecclesial authority indicate that all the discussions on this subject require a theological response and theological reasons concerning the ecclesial character of the power and decisions binding the Church community. The bishop of Eichstät, Gregor Maria Hanke, drew attention to this element stating that in the beginning it should be explained to what extent the decisions made during the discussion can be binding. ${ }^{19}$ Without prior and clear explanation of the nature of the decisions taken by the congregation, the congregation can deny what it exists for and reduce this kind of assembly to one of the forms characteristic for non-ecclesial policies. "The arrogance of auto-dogmatization will definitely not heal the Church in the future." ${ }^{20}$ However, the solution does not lie in the negation of the stances expressing such a belief. It does not lead to

${ }_{17}$ Marek Trojan, "Arcybiskup Kolonii przestrzegł przed schizmą w Kościele w Niemczech," accessed November 4, 2019,

https://kresy.pl/wydarzenia/arcybiskup-kolonii-przestrzegl-przed-schizma-w-kosciele-wniemczech/.

18 eKAI.pl, "Niemieccy biskupi odrzucają stanowisko Watykanu ws. drogi synodalnej."

${ }^{19}$ Ibid.

${ }^{20}$ Ratzinger, "Demokratyzacja Kościoła?," 61. 
any explanations but, instead of provoking deeper self-reflection, leads to bigger and bigger separation and also further loss of trust. "The era of democracy is a challenge for the Church. The challenge it has to face up to in a critical and, at the same time, open-minded way," Ratzinger continues. ${ }^{21}$

\section{Synodal and Personal Structure of Power in Church}

The problem of philosophical interpretation of the issues and usefulness of the proposed solutions regards the reality to which it refers to. Therefore, one should start with its description. The reality is the Church and the tasks it is entrusted with by Christ, through which his person is made present. All the baptized people participate in Christ's priesthood in a given manner due to the substantial difference between hierarchical and universal priesthood. The reason for the difference between these two types of priesthood is not the relation of primacy or subordination (they differ from one another not only in degree but in essence ${ }^{22}$ ), which could be described in the category of quantity but the essential difference that indicates a new kind of priestly mission and power. The difference does not concern the jurisdictional nature but the sacramental one, which means that the priest, contrary to the lay faithful, is an effective sign of the presence of Christ in His Church, of which $\mathrm{He}$ is the Lord. ${ }^{23}$

The issue of synodality and participation in the exercising of power in the Church might only become comprehensible with regard to the communion structure of the Church which is based on the intermingling (immanence) of the universal Church and particular churches. This idea is opposed by the principle of autocephality of the particular Church (the universal Church as a federation of particular churches) and the principle of the monistic concept of the Church, according to which particular churches serve the function of administrative districts within the universal Church. According to the teaching of the Second Vatican Council, the universal Church and the particular Church reflect two constitutive dimensions of one Church of Christ. ${ }^{24}$ It is not appropriate to recognize the relations between two intermingling dimensions in the Church using

${ }^{21}$ Ibid., 62.

${ }^{22}$ Vatican Council II, Dogmatic Constitution on the Church Lumen Gentium (21.11.1964), n. 10.2

${ }^{23}$ Gisbert Greshake, Być kapłanem dzisiaj (Poznań: Wydawnictwo W Drodze, 2010), 159160.

${ }^{24}$ Gerosa, Interpretacja prawa w Kościele, 182. 
the political criteria of centralization or decentralization, or by referring to the principle of subsidiarity. The universal Church, which exists through particular Churches, is present in the particular Church. All the issues regarding power and exercising it in the Church, as well as participation in it, should be recognized in the light of communio Ecclesiarum.

Today's voices demanding participation in taking binding decisions, that is, in fact, participation in exercising power, seem to refer to the scholastic concept of the episcopal power (Stephen of Tournai), according to which the power of Holy Orders (potestas ordinis) was separated from the power of jurisdiction (potestas iurisdictionis). The latter was not, according to how the centuries-long tradition was understood, granted by virtue of the sacrament of Holy Orders but the mission received by a bishop from the pope.

The issue of participation in exercising power is related to the power of governance and teaching. The division of power in the light of conciliar teaching about it becomes an old-fashioned category and there is no point using it. However, subconscious referral to it requires an explanation why due to communio nature and one power in the Church the above categories lose rationality. While the above categories are still being used, one should always remember about the lack of objective distinction between them. The possibility of differentiation might concern only the formal level, since these are two different formal ways of exercising the only power of the same saving content.

The issue of participation in the Church power requires defining the character of the power in the first place. The conciliar concept of the Church power is based on two principles: (1) sacramental origin; (2) inseparability of the personal and synodal element. Power in the Church is the element anticipating the Church. It does not have a delegated character. ${ }^{25}$ It is fully granted to bishops in the sacrament of Holy Orders ${ }^{26}$ The personal character of power results from its sacramental character. Only the bishop personally represents Christ who works through him ex opere operato. He is the only one to represent the particular Church within the universal Church and the universal Church inside the particular one.

The opposite to the bishop's personal action is the activity undertaken by bishops as a college in which the will of an individual integrates with the will of the college as the will of the responsible entity. It is not a synodal character of the bishop's activity. Synodality and personality are not in contraposition. The synodal dimension of the personal power results from its sacramental character. Synodal foundation of exercising power lies within the communion structure of the Church, in which each bishop receives from Christ the same power of re-

${ }^{25}$ Eugenio Corecco, "Sinodalità e partecipazione nell'esercizio della «potestas sacra»," in Eugenio Corecco, Ius et Communio. Scritti di Diritto Canonico (Casale Monferato: PIEMME, 1997), 112.

${ }^{26}$ Lumen Gentium, 27, 1. 
vealing in a legally binding way the unity of word and sacrament. The dynamics of the communion between particular churches and the universal Church at the ontological level is reflected at the operational level in the dimension of synodality, which does not have its source in casual relationships between bishops, but in their reference to the Petrine ministry. It was mentioned by Pope Francis when he made a speech on the 50th anniversary of the Synod of Bishops, stating that bishops are united with the Bishop of Rome with the bond of episcopal communion (cum Petro), and, at the same time, they are subordinate to him as the head of the college (sub Petro). ${ }^{27}$

In the same speech the pope added, reminding the words of Saint John Chrysostom, that "the Church and Synod are synonyms." Therefore, synodality is a form of exercising power which is not an alternative to a personal character. The two forms intermingle, which results from their ontological unity even if one of them may prevail over the other. The act of the bishop's power always remains a personal and synodal act since only thanks to such character of power can he exercise it over God's people entrusted to him. Synodality gives a deeper meaning and, to some degree, extends the episcopal ministry as it thus shows the relations between all the services in the Church, as well as it expresses its communion nature. ${ }^{28}$ This structure is rooted in the word and sacrament as the elements previously granted by Christ, whereupon the Church is created and developed. As such, they cannot be subject to being changed by free will.

\section{Degrees of Participation in the Power of the Church}

Synodality, which is an ontological dimension of power in the Church, does not concern only the bishops but also those who received it (presbyters and deacons). However, it can only be discussed analogically to the synodality of bishops. They do not fully participate in Christ's power, but merely in the fullness of power of the episcopal ministry. Lack of sacramental autonomy causes that the synodal character of their service cannot be recognized as equal with the synodal character of the episcopal ministry. It may concern only a par-

${ }^{27}$ Francis, Ceremony Commemorating the 50th Anniversary of the Institution of the Synod of Bishops, 17.10.2015, accessed November 15, 2019,

http://www.vatican.va/content/francesco/en/speeches/2015/october/documents/papa-francesco_20151017_50-anniversario-sinodo.html.

${ }^{28}$ Gerosa, Interpretacja prawa w Kościele, 188. 
ticular church, and in the universal Church only under the mandate granted by the College of Bishops itself. Synodality of the presbyters has its foundations in the synodality of the universal Church as its structural element. Thus, the presence of presbyters in a particular church is the consequence of the existence of synodality of the universal Church, and not only the result of the pastoral needs of the bishop. The monistic structure of the Church organized only around the bishop would not be able to fulfil the synodal nature of the Church and thus would not reflect the mutual immanence of the universal Church and a particular one. ${ }^{29}$

The synodal character of the Church is also made present in relation to the lay faithful. It results from the universal priesthood, which is anticipatory towards the ministerial (hierarchical) priesthood but, at the same time, different from it. In the past, laymen participated in various congregations of synodal character. At present, it is also possible with the consent of the College of Bishops. Medieval councils were not only the congregation of the Church but of the whole Latin Christianity with the elements of political and economic assembly. Laymen as the representatives of secular power had a casting vote in the matters connected with the relations with the outside world. With regard to the Church matters, the principle of the first "council" in Jerusalem was applicable, at which debates were conducted in front of the whole Church, but decisions were made by the Apostles and the elders (Dz 15, 6. 22). ${ }^{30}$

Contrary to bishops and presbyters, a secular person, who by virtue of baptism takes part in Christ's triple mission, does not participate in the episcopal ministry, whose function is creating the Church on the basis of communion bonds granted to the faithful through baptism and protection of the authenticity of the Word and Sacrament together with a guarantee of the unity of the Church communion. ${ }^{31}$ Synodality is the essential element of the episcopal ministry and therefore imposes on each bishop a responsibility to implement it. Lay faithful might be called to participate in synodal acts but it is not their duty for ontological reasons, such as lack of participation in the episcopal ministry. Thus, lay faithful can be allowed to exercise the power of governance, in accordance with the provisions of law (can. $129 \S 2$ ). However, the principles of this collaboration are referred to as cooperation (cooperatio), because such a form does not assume participation in power of the subject holding it. In case of presbyters, who are not granted the fullness of the sacrament of Holy Orders, their cooperation refers to the participation in the power of the episcopal ministry and not only to its implementation. With respect to lay faithful, what comes into play is only cooperation in exercising the power of governance and entrusting them with

${ }^{29}$ Corecco, "Sinodalità e partecipazione nell'esercizio della «potestas sacra»," 113-115.

${ }^{30}$ Ratzinger, "Demokratyzacja Kościoła?," 37- 39.

${ }^{31}$ Eugenio Correco, "Sinodalità," in Eugenio Corecco, Ius et Communio. Scritti di Diritto Canonico (Casale Monferato: PIEMME, 1997), 77. 
ministries intended to fulfil spiritual purposes or connected with pastoral tasks (cann. $145 \S 1,151,228 \S 1,536,874$ ).

\section{The Theory of Participation}

Synodality and participation are expressions describing the reality of the Church communion. Their source is in one communio, whose validation is on the structural level of relationality of specific Church communities. They indicate two different dimensions of these relations. Synodality is a specific and characteristic element of sacramental ministry resulting from the ministry of the bishop and presbyter. The category of participation refers to the activity of lay faithful in their relationship with the sacramental ministry. Both dimensions of the Church reality occur simultaneously and are inseparable because they result from the nature of interpersonal relations in the Church community.

The Church exists as communio not only in an individual dimension but also a community one. As an organic community of communities it does not realize itself only by individual relationships creating its reality, but it contains co-participation of different community organisms mutually associated and intermingling. In such a community, there exist interpersonal bonds, unique and typical of it, in which the elements of divine origin become one with the human elements. By the very fact of being incorporated into the Church, the elements of social and natural interpersonal relations do not disappear, but they gain a new meaning, transformed and refined with divine elements. This dimension of the Church community affects the rights and responsibilities of all the faithful in one community of the Church. ${ }^{32}$

The participation of the faithful in the implementation of the triple mission of Christ is realized by the testimony of faith, which constitutes their contribution to the building of the Church community. It results from the participation in universal priesthood of all faithful, in which sensus fidei corresponds with the accepted and proclaimed Word. Such an intention of believers' faith should not be ignored in formulating judgements of doctrinal nature by bishops and presbyters. ${ }^{33}$ An example of such sense of faith are some dogma of faith, whose proclamation was an appreciation of the convictions and faith of believers. The testimony of faith enjoying autonomy based on the sacrament of baptism is not synonymous with the demanding attitude of the participation in the fullness of episcopal power or the power of presbyters, whose source is in the sacrament

\footnotetext{
${ }^{32}$ Żurowski, Wspótuczestnictwo kościelne, 61-63.

${ }^{33}$ Corecco, "Sinodalità e partecipazione nell'esercizio della «potestas sacra»," 128-129.
} 
of Holy Orders. Universal priesthood as well as ministerial one are two inseparable elements establishing the Church structure, although in an essentially different way.

Participation in the power of governance refers to the category of having or not the competences which allow undertaking sovereign operations. Possessing them provides an opportunity to undertake such operations, which is equivalent to participation. Such possibilities are granted by current law of the Church, allowing lay faithful to hold Church offices to realize the spiritual goal. ${ }^{34}$

The same word-participation - is used by Karol Wojtyła while describing the person's activities performed together with other people. Philosophical meaning of participation guides us to search for the foundations of such action. In this context, it can turn out to be useful for describing the participation of the faithful in the power of governance. The question posed in the context of communio principle concerning the foundations of such action has its answer in the character of synodality of the Church community and sacred power in the Church. However, it can contribute to the understanding of the action which is not reduced only to the forms provided for it by the law. It concerns personal actions as a testimony of faith in these forms. Wojtyła writes that "the characteristic of participation indicates that a man acting together with other people retains in this action the personalistic value of his own act and, at the same time, implements what results from joint actions," that is, in other words, "thanks to participation a man acting together with other people retains everything that results from joint actions and, in this way, implements the personalistic value of his own act." ${ }^{35}$ Thus, the person acting with others fulfils himself. ${ }^{36}$ It is not important whether a man acting with other people "chooses what the others choose or even when he chooses because others do it, seeing in such an object of choice somehow his own and homogeneous value." ${ }^{37}$ In consequence, the person can experience the decisions made by the community as his own, which happens when choices are directed at the common good and are made as part of joint responsibility (co-responsibility). A privileged place for such decisions certainly are communities which are homogeneous in some sense, whose members are connected with similar or even the same bonds which provoke taking joint decisions. ${ }^{38}$

In Wojtyła's formulations concerning cooperation with others by way of participation, one can find elements which determine that it truly relates to partici-

${ }^{34}$ Carmen Peña, "Sinodalidad y laicado. Corresponsabilidad y participación de los laicos en la vocación sinodal de la Iglesia.” Ius Canonicum 59, n. 118 (2019): 746-756.

${ }^{35}$ Wojtyła, Persona e atto, 630.

36 Ibid., 632-634.

37 Ibid., 634-636.

38 Rocco Buttiglione, Il pensiero dell'uomo che divenne Giovanni Paolo II (Milano: Mondadori, 1998), 203-204. 
pation and not some other form of joint action. These are: the co-existence of the community of action with the personalistic value of the act and experiencing as one's own jointly made decisions.

According to Wojtyła, the Church community as a homogeneous community designated by the Word and the Sacrament is a privileged place for various forms of participation. The impassable border for the possibility of joint action is constituted by the episcopal ministry together with the power granted to it, and thus we can observe the lack of possibility of joint action by lay faithful and clergymen while making these decisions which are connected with the held power.

Therefore, it is difficult to exclude secular persons from the category of participation in a broader range referring to the testimony of faith together with the clergy. Such acts will be simultaneously individual, emphasizing their entirely personal and communal character. They are performed in syntony with the acts undertaken by virtue of power, acknowledged as one's own. In this sense, one can declare the participation of lay faithful in the Church power. In case of the lack of agreement on sovereign decisions and lack of identification with them, it is hard to talk about any forms of participation since the essence of participation is retaining personal character of one's own acts. However, clergymen making sovereign decisions and involving in it the faithful entrusted to them, and thus engaging them in participation should listen to the "voice of the people," which is the voice of the Christian community and not only its chosen representatives, often usurping the right to speak on behalf of the whole community. Joint listening to the Word which lives in the Sacrament is the dimension of the community's life, "which is difficult to be put into a legal framework; however, despite this it has great value." 39

The category of participation in philosophical terms seems to be more productive in building the Christian community than when used in recognizing it in the state and political systems, while making use of the models unfamiliar to the Church. The latter ones demand constant revelation of differences in meaning with regard to the Church community. They also have some negative connotation since they have impact on the feeling of separation between a believer and a clergyman by way of state power and citizens that are subjected to it. Philosophical understanding of participation and building joint responsibility around it has a positive tone. In this light, the bond existing between all the faithful by virtue of universal priesthood might adopt a more comprehensible dimension contributing to the development of the Church community. The encouragement

${ }^{39}$ Ratzinger, "Demokratyzacja Kościoła?," 60. 
to participate calls for deeper insight into the faith of the Church, in which each baptized person becomes a depositary. However, this process requires from clergymen meeting two conditions: noticing and accepting sensus fidei and opening to the theology of synodality.

\section{Bibliography}

Buttiglione, Rocco. Il pensiero dell'uomo che divenne Giovanni Paolo II. Milano: Mondadori, 1998.

Correco, Eugenio. "Sinodalità." In Eugenio Corecco, Ius et Communio. Scritti di Diritto Canonico, 39-81. Casale Monferato: PIEMME, 1997.

Corecco, Eugenio. "Sinodalità e partecipazione nell'esercizio della «potestas sacra»". In Eugenio Corecco, Ius et Communio. Scritti di Diritto Canonico, 109-129. Casale Monferato, PIEMME, 1997.

Francis. Ceremony Commemorating the 50th Anniversary of the Institution of the Synod of Bishops (November 17, 2017). Accessed November 5, 2019. http://www.vatican.va/content/ francesco/en/speeches/2015/october/documents/papa-francesco_20151017_50-anniversariosinodo.html.

Francis. Al Popolo di Dio che è in cammino in Germania (June 9, 2019). Accessed November 4, 2019. http://w2.vatican.va/content/francesco/it/letters/2019/documents/papa-francesco_20190629_lettera-fedeligermania.html.

Gerosa, Libero. Interpretacja prawa w Kościele, zasady, wzorce, perspektywy. Kraków: WAM, 2003.

Greshake, Gisbert. Być kapłanem dzisiaj. Poznań: Wydawnictwo W Drodze, 2010.

International Theological Commision. Synodality in the Life and Mission of the Church (March 2, 2018). Accessed May 18, 2020. http://www.vatican.va/roman_curia/congregations/cfaith/ cti_documents/rc_cti_20180302_sinodalita_en.html.

eKAI.pl. "Niemieccy biskupi odrzucają stanowisko Watykanu ws. „drogi synodalnej.” Accessed November 4, 2019. https://ekai.pl/niemieccy-biskupi-odrzucaja-stanowisko-watykanu-wsdrogi-synodalnej/.

eKAI.pl. "Nuncjusz wzywa niemieckich biskupów do posłuszeństwa papieżowi." Accessed November 4, 2019. https://ekai.pl/nuncjusz-wzywa-niemieckich-biskupow-do-posluszenstwapapiezowi/.

Peña, Carmen. "Sinodalidad y laicado. Corrsponsabilidad y participación de los laicos en la vocación sinodal de la Iglesia." Ius Canonicum 59, n. 118 (2019): 731-765.

Ratzinger, Joseph. „Demokratyzacja Kościoła?”. In Demokracja w Kościele. Możliwości i ograniczenia, ed. Joseph Ratzinger and Hans Maier, 5-62. Kraków: Wydawnictwo Salwator, 2005.

Savignano, Aristide. "Partecipazione." In Enciclopedia del diritto, vol. 32, 1-14. Milano: Giuffrè, 1982.

Tomasik, Krzysztof. “Droga synodalna - tak, ale dokąd?” Accessed November 4, 2019. https://ekai.pl/droga-synodalna-tak-ale-dokad/.

Trojan, Marek. "Arcybiskup Kolonii przestrzegł przed schizmą w Kościele w Niemczech.” Accessed November 4, 2019. https://kresy.pl/wydarzenia/arcybiskup-kolonii-przestrzegl-przedschizma-w-kosciele-w-niemczech. 
Vatican Council II. Decree on the Mission Activity of the Church Ad gentes divinitus (December 12, 1965).

Vatican Council II. Dogmatic Constitution on the Church Lumen Gentium (November 21, 1964).

Wojtyła, Karol. Persona e atto. Testo polacco a fronte. Santarcangelo di Romagna: Rusconi Libri, 1999.

Żurowski, Marian. Wspótuczestnictwo kościelne. "Ius ad Communionem.” Kraków: WAM, 1979.

Tomasz Gałkowski

Participation à la «voie synodale»:

Quelques commentaires à la lumière de la théorie de la participation de Karol Wojtyta

\section{Résumé}

L'annonce dans l'église allemande dudit chemin synodal a suscité des discussions sur la participation et la coresponsabilité de tous les fidèles dans la mission de l'Église, notamment en ce qui concerne l'exercice de l'autorité et la prise de décisions contraignantes. L'objectif des réflexions présentées dans cet article est d'examiner la discussion à la lumière de la théorie de la participation analysée par Karol Wojtyła dans son ouvrage La personne et l'action. La coexistence d'une communauté d'action et la valeur personnelle d'un acte ainsi que l'expérience de décisions prises conjointement peuvent orienter de nouveaux paradigmes d'exploration du sensus fidei.

Mots-clés: voie synodale, participation, Karol Wojtyła, théorie de la participation

Tomasz Gałkowski

Partecipazione al "percorso sinodale":

Alcuni commenti alla luce della teoria della partecipazione di Karol Wojtyta

\section{Sommario}

L'annuncio nella Chiesa tedesca del cosiddetto cammino sinodale ha suscitato discussioni sulla partecipazione e corresponsabilità di tutti i fedeli nella missione della Chiesa, soprattutto per quanto riguarda l'esercizio della potestà e il processo decisionale. L'obiettivo delle riflessioni presentate in questo articolo è quello di esaminare la discussione alla luce della teoria della partecipazione analizzata da Karol Wojtyła nel suo libro La persona e l'azione. La coesistenza di una comunità d'azione e il valore personale dell'atto così come l'esperienza delle decisioni prese congiuntamente possono orientare nuovi paradigmi di esplorazione del sensus fidei.

Parole chiave: cammino sinodale, partecipazione, Karol Wojtyła, teoria della partecipazione 